\title{
Genetic polymorphisms at the leptin receptor gene in three beef cattle breeds
}

\author{
Sabrina E.M. Almeida ${ }^{1}$, Luciana B.S. Santos ${ }^{2}$, Daniel T. Passos ${ }^{2}$, Ângela O. Corbellini ${ }^{2}$, \\ Beatriz M.T. Lopes ${ }^{1}$, Cláudia Kirst ${ }^{1}$, Gustavo Terra ${ }^{3}$, Jairo P. Neves ${ }^{4}$, Paulo B.D. Gonçalves ${ }^{3}$, \\ José C.F. Moraes ${ }^{5}$ and Tania de Azevedo Weimer ${ }^{2}$ \\ ${ }^{1}$ Departamento de Genética, Universidade Federal do Rio Grande do Sul, Porto Alegre, RS, Brazil. \\ ${ }^{2}$ Laboratório Biotecnologia, Hospital Veterinário, Universidade Luterana do Brazil, Canoas, RS, Brazil. \\ ${ }^{3}$ Departamento de Clínica de Grandes Animais, Universidade Federal de Santa Maria, Santa Maria, RS, \\ Brazil. \\ ${ }^{4}$ Universidade de Brasília, Brasilia, DF, Brazil. \\ ${ }^{5}$ Empresa Brasileira de Pesquisa Agropecuária, Pecuária Sul, Bagé, RS, Brazil.
}

\begin{abstract}
The genetic diversity of a single nucleotide polymorphism (SNP) at the exon 20 (T945M) of the leptin receptor gene (LEPR) and of three short tandem repeats (STRs BM7225, BMS694, and BMS2145) linked to LEPR was investigated in three beef cattle herds (Brangus Ibagé, Charolais, and Aberdeen Angus). A cheap and effective new method to analyze the T945M polymorphism in cattle populations was developed and the possible role of these polymorphisms in reproduction and weight gain of postpartum cows was evaluated. High levels of genetic diversity were observed with the average heterozygosity of STRs ranging from 0.71 to 0.81 . No significant association was detected between LEPR markers and reproductive parameters or daily weight gain. These negative results suggest that the LEPR gene polymorphisms, at least those herein described, do not influence postpartum cows production.
\end{abstract}

Key words: molecular markers, genetic diversity, cattle production, LEPR gene polymorphisms.

Received: August 22, 2007; Accepted: March 13, 2008.

\section{Introduction}

Low bovine fertility rate is associated with suboptimal nutrition and is a major concern of livestock cattle production systems. Recently, much effort has been devoted to understand the role of the leptin protein and its receptor in regulating food intake and reproduction in ruminants (Chilliard et al., 2005).

Leptin is secreted by adipose tissues and acts especially through its receptor on the hypothalamus, the center of energy homeostasis, as well as on ovarian follicular cells, on placenta and lactating mammary glands (Bartha et al., 2005; Chilliard et al., 2005). The leptin receptor (LEPR) is a member of the cytokine I family of receptors and signal transducers. Comparisons of the bovine LEPR DNA sequence with that of humans and mice indicated $81 \%$ and $75 \%$ of sequence identity, respectively (PfisterGenskow et al., 1997). In ruminants, LEPR expression seems to be affected by high and low nutrition levels (Chil-

Send correspondence to Tania de Azevedo Weimer. Laboratório Biotecnologia, Hospital Veterinário, Universidade Luterana do Brazil, Rua Duque de Caxias 910, apartment 101, 90010-280 Porto Alegre, RS, Brazil. E-mail: taw@gmail.com. liard et al., 2005) and blood leptin concentrations seem to interfere in luteinizing hormone secretion (Kadokawa et $a l ., 2006)$ and to stimulate growth hormone release (Nonaka et al., 2006).

Many studies concerning the relationship between LEPR gene polymorphisms and weight gain have been conducted in rodents and humans (Banks and Farrell, 2003, Park et al., 2006), but few data are available for ruminants, which present different complexity levels concerning digestion and cerebral metabolic sensors (Chilliard et al., 2005).

The LEPR gene is located on bovine chromosome $3 q 33$ (Pfister-Genskow et al., 1997) and several polymorphisms have been mapped in this chromosome, such as the short tandem repeats BM7225 at $101.7 \mathrm{cM}$, BMS694 at $94.6 \mathrm{cM}$, and BMS2145 at 93.8 (Kappes et al., 1997). Inside the LEPR gene, Liefers et al. (2004) described a missense mutation T945M (Table1).

In this study the genetic variability of the polymorphisms described above was analyzed in three beef cattle herds, enabling the description of a new methodology to investigate the T945M polymorphism, and the evaluation of the possible role of these polymorphisms in reproduction and weight gain in these herds. 
Table 1 - Molecular markers mapped at BTA3 and analyzed in the present paper.

\begin{tabular}{|c|c|c|c|c|c|}
\hline STRs & GenBank number & Observed allele sizes & Primers $^{1}$ & $\begin{array}{l}\text { Annealing } \\
\text { temperatures }\end{array}$ & References \\
\hline BM7225 & G18790 & $96-114$ & $\begin{array}{l}\text { GGTGTTATGCATTCTCTAGGTGC } \\
\text { AAGAGTTAGACATGACTGAGCACG }\end{array}$ & $60^{\circ} \mathrm{C}$ & Kappes et al., 1997 \\
\hline BMS694 & G18739 & $135-153$ & $\begin{array}{l}\text { AAACTCTAGGTCCATCCAGGTT } \\
\text { AGATGTGGAAGTGTCCATCAA }\end{array}$ & $58^{\circ} \mathrm{C}$ & Kappes et al., 1997 \\
\hline BMS2145 & G18925 & $148-164$ & $\begin{array}{l}\text { ATGGAAGTGGCTTAAGTGTCC } \\
\text { GCAAATAACCTCCATATTGCTG }\end{array}$ & $58^{\circ} \mathrm{C}$ & Kappes et al., 1997 \\
\hline $\mathrm{T} 495 \mathrm{M}$ & AJ580801 & $\begin{array}{c}T: 67,130 \\
M: 37,67,93\end{array}$ & $\begin{array}{l}\text { ACTACAGATGCTCTACTTTG } \underline{ } \\
\text { TGCTCCTCCTCAGTTT }\end{array}$ & $56-50{ }^{\circ} \mathrm{C}^{2}$ & This paper \\
\hline
\end{tabular}

${ }^{1} \mathrm{~T} 495 \mathrm{M}$ primers are those employed in the present paper, and not those described by Liefers et al., 2004; ${ }^{2}$ Touchdown PCR.

\section{Materials and Methods}

Blood samples from three beef cattle herds [Aberdeen Angus (AA, $\mathrm{n}=98)$, Charolais $(\mathrm{C}, \mathrm{n}=83$ ), and Brangus Ibagé $(n=160)$ ] were obtained from the jugular vein using acid-citrate-dextrose (ACD) as anticoagulant (Almeida et al., 2003) and following the Principles of Veterinary Medical Ethics ("Código de Ética Profissional do Médico Veterinário") and the International Guiding Principles For Biomedical Research Involving Animals (1985).

$\mathrm{AA}$ and $\mathrm{C}$ animals had been evaluated in a previous study which compared the efficiency of different hormonal treatments associated with 96-hour calf removal in relation to complete weaning of animals fed with different forages and analyzed the interaction between fertility and weight gain in postpartum (Terra et al., 2008). The animals were adult cows (ages ranging from 4 to 6 years), with mean body condition of 3.0 (in a classification range from 1 very thin - to 5 - very fat; Lowman et al., 1973) at partum. Fifty to 70 days postpartum, the cows were sorted into six groups (A0, A2, A5, B0, B2, and B5) according to their body condition at partum. They were then submitted to different forage availabilities and hormonal treatments: A groups were managed on native pasture with $960 \mathrm{~kg}$ dry matter per hectare $\left(\mathrm{DM} \mathrm{ha}^{-1}\right)$ and a stocking rate of 0.96 animal unit per hectare $\left(\mathrm{au} \mathrm{ha}^{-1}\right.$; au $=400 \mathrm{~kg}$ live weight $)$ at partum, and $400 \mathrm{~kg} \mathrm{DM} \mathrm{ha}^{-1}$ at weaning; B groups were also managed on native pasture but with $600 \mathrm{~kg} \mathrm{DM} \mathrm{ha}^{-1}$ and a stocking rate of $1.44 \mathrm{au} \mathrm{ha}^{-1}$ at partum and $240 \mathrm{~kg} \mathrm{DM} \mathrm{ha}^{-1}$ at weaning. The dry matter of the pasture was estimated by the double sample method (Wilm et al., 1944). A0 and B0 were definitely separated from their calves at day 7 from the beginning of the experiment. A2, A5, B2, and B5 were submitted to estradiol benzoate [2 $\mathrm{mg}(\mathrm{A} 2, \mathrm{~B} 2)$ or $5 \mathrm{mg}$ (A5, B5)], plus a progesterone (P4) vaginal implant; six days later they received 1000 UI of equine chorionic gonadotropin and in the following day the vaginal implant was removed and the cows were separated from their calves for $96 \mathrm{~h}$. All animals were weighed twice (at partum and at weaning). The cows that showed estrous between days 7 and 17 from the beginning of the treatment were artificially inseminated; they were then bred with a cow:bull ratio of
100:12 up to day 67 ; clinical and ultrasonic pregnancy diagnoses were performed on day 60 from the beginning of the experiment to calculate the proportion of cows that conceived in the first estrous after treatment, and on day 127 to estimate final pregnancy rate.

The Brangus Ibagé (BI) breed is a composite beef cattle herd (5/8 Aberdeen Angus x 3/8 Nelore) resulting from the crossing between Aberdeen Angus cows (Bos primigenius taurus) and Nelore bulls (Bos primigenius indicus) performed by the Brazilian Agricultural Research Corporation (EMBRAPA Pecuária Sul, Bagé, RS, Brazil). Breeding procedures include single sire mating in small paddocks, in groups of about 40 females for paternity identification purposes. The selection program began in 1945, with emphasis on body weight measurements at birth, at weaning adjusted to 205 days, and at 18 months of age, without any special selection for fertility. All animals have been exclusively managed on native pasture in an extensive livestock system (Oliveira et al., 1998), with the mating season extending from November 15th to February 15th. Lifetime calving interval data (CI) were obtained for the females of the experimental herd as described by Oliveira et al. (2002). As an indicator of cow fertility, the weight at first calving (WFC) was computed as a predictor for growth potential of the heifers. From a total of 287 cows from this herd, samples were obtained from 160 animals for which there was available information about at least three calving intervals.

Genomic DNA was extracted from peripheral blood (Miller et al., 1988). Three STRs [BM7225 (D3S75), BMS694 (D3S66), and BMS2145 (D3S64)] linked to the LEPR gene were PCR-amplified by standard methods with specific primers and annealing temperatures (Table 1). The amplicons were analyzed by vertical electrophoresis in $10 \%$ non-denaturing polyacrylamide gels (Sambrook and Russel, 2001).

The SNP T945M, which maps at the exon 20 of the LEPR sequence and corresponds to a mutation in the intracellular region of the functional protein, was also analyzed. This mutation was previously investigated by DNA sequencing (Liefers et al., 2004). In order to screen this mutation, we used a method that introduces a point mutation into 
one of the primers so that the PCR product contains a FokI restriction site. Primers 5' ACTACAGATGCTCTACTT TGE 3' and 5' TGCTCCTCCTCAGTTT 3' (the underlined nucleotide corresponds to the mutation introduced) amplify a 197-base pair (bp) fragment. After digestion with FokI, the MM animals presented 93-, 67-, and 37-bp fragments, while TT animals showed 130-, and 67-bp fragments (Figure 1). The PCR was performed with an annealing temperature of the reaction decreasing $1{ }^{\circ} \mathrm{C}$ from $56{ }^{\circ} \mathrm{C}$ every second cycle to a 'touchdown' at $50{ }^{\circ} \mathrm{C}$, at which temperature 34 cycles were carried out. Each cycle consisted of $94^{\circ} \mathrm{C}$ for $20 \mathrm{~s}, 15 \mathrm{~s}$ at the annealing temperature and $72{ }^{\circ} \mathrm{C}$ for $20 \mathrm{~s}$ followed by a final extension at $72{ }^{\circ} \mathrm{C}$ for $5 \mathrm{~min}$. The cleavage products were analyzed by vertical electrophoresis in $10 \%$ non-denaturing polyacrylamide gels (Sambrook and Russel, 2001).

Allele and genotype frequencies were determined by direct counting. The expected heterozygosity $(\mathrm{H})$ and average expected heterozygosity were both estimated according to Nei (1978). Association analyses were performed using the General Linear Models of SPSS ${ }^{\circledR}$ for WindowsTM software (SPSS Inc), version 10.0.5 (1999), according to the following models:

For A. Angus and Charolais:

$Y_{i j k l m}=\mu+\beta B_{i j k l m}+F_{j}+H_{k}+G_{l}+F^{*} H_{j k}+F^{*} G_{j l}+$ $H^{*} G_{k l}+F^{*} H^{*} G_{j k l}+e_{i j k l m}$

where $Y_{i j k l m}$ is the $m^{\text {th }} \mathrm{ADG}$ (in grams), $\mathrm{P} 1$, or $\mathrm{P} 2$ record of the $i^{\text {th }}$ cow; $\mu$ is the effect of the population mean; $\beta B_{i j k l m}$ is the covariate effect of the body score condition; $F_{j}$ is the effect of forage availability; $H_{k}$ is the effect of hormone treatment; $G_{l}$ is the effect of the marker genotype; and $e_{i j k l m}$ is the random error component.

For B. Ibagé:

$Y_{i j k l m}=\mu+\beta W_{i j k l m}+S_{j}+Y_{k}+G_{1}+S^{*} Y_{j k}+S^{*} G_{j l}+$ $Y^{*} G_{k l}+S^{*} Y^{*} G_{j k l}+e_{i j k l m}$

where $Y_{i j k l m}$ is the $m^{\text {th }} \mathrm{CI}$ (average of all CI information, in days) record of the $i^{\text {th }}$ cow; $\mu$ is the effect of the population

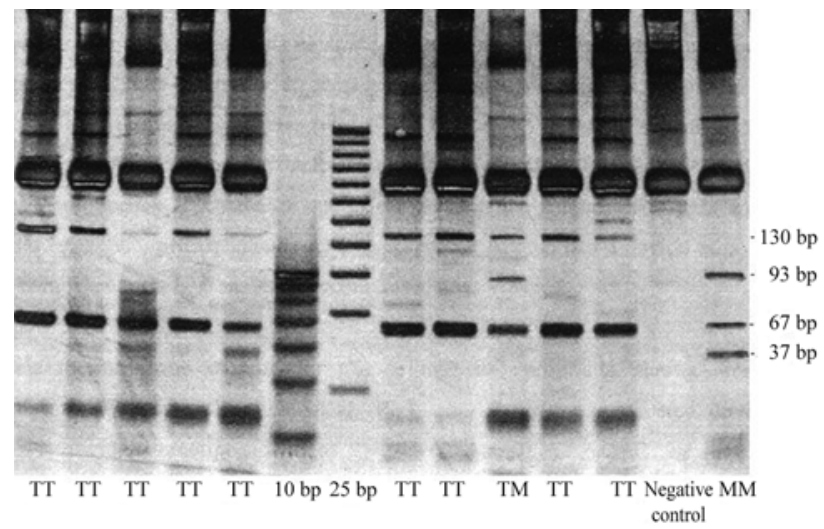

Figure 1 - Polyacrylamide gel electrophoresis showing the T945M mutation genotypes analyzed through the PCR/RFLP method. mean; $\beta W_{i j k l m}$ is the covariate effect of the weight at calving, $S_{j}$ is the effect of calf sex, $Y_{k}$ is the year of partum, $G_{1}$ is the effect of the marker genotype, and $\mathrm{e}_{\mathrm{ijklm}}$ is the random error component. And

$$
Y_{i j}=\mu+A_{i}+e_{i j}
$$

where $Y_{i j}$ is the $j^{\text {th }}$ WFC phenotype of the $i^{\text {th }}$ individual; $\mu$ is the effect of the population mean; $A_{i}$ is the effect of the ith genotype class; and $e_{i j}$ is the random error component.

Descriptive statistics was carried out beforehand to verify the normality of the distribution of the productive parameters. Then, CI data were normalized by natural logarithmic transformation.

\section{Results}

Gene frequencies varied among populations (Table 2), but the most frequent alleles were $B M 7225^{*} 96$, $B M S 694 * 145, B M S 2145 * 154$ and $T 495 M * T$. Some alleles were observed only in one population: $B M 7225 * 98$ in Charolais animals, BMS694*149 and BMS694*153 in Brangus Ibagé, and BMS694*135 in Aberdeen Angus. The PCR-RFLP method employed to screening the T945M SNP permitted the identification of both alleles. The $M$ allele was present at a low frequency and only one MM homozygous individual was observed (in the Charolais population). The expected heterozygosity values $(\mathrm{H})$ were high in the STR systems, with a mean value ranging from 0.71 in AA to 0.81 in BI (Table 2).

Descriptive statistics (mean \pm standard error) for CI and $\mathrm{WFC}$ in $\mathrm{BI}$, as well as ADG and pregnancy rates (in percent) on day 60 (P1) and 127 (P2) for AA and C cows (according to treatment groups) are shown in Table 3. No differences were observed in ADG, P1 or P2 among the several nutrition and hormone treatment groups in $\mathrm{AA}$ or $\mathrm{C}$ breeds. The association analyses performed between genotype classes and CI and WFC in Brangus Ibagé indicated no significant result. Also, no difference between ADG, P1 or P2 and genotypes was detected in Aberdeen Angus or in Charolais. The simultaneous comparison of these two herds also failed to reveal any significant association. For this last analysis, the mean ADG value was corrected considering herd weight to compensate the sharp differences in this parameter between Charolais (232.1 \pm 2.5$)$ and Aberdeen Angus $(103.4 \pm 2.0)$. No interaction between genotypes, hormone treatment or nutrition was observed.

\section{Discussion}

The STRs linked to the LEPR gene herein investigated presented high variability in the three populations. Although Charolais and Aberdeen Angus herds have a long history of artificial selection, these procedures have not reduced their genetic variability, at least for the polymorphisms investigated. The higher variability in STR systems observed in Brangus Ibagé as compared to the other two 
Table 2 - Allele frequencies and heterozygosities $(\mathrm{H})$ in Brangus Ibage (BG), Charolais (C), and Aberdeen Angus (AA) breeds.

\begin{tabular}{|c|c|c|c|}
\hline \multirow[t]{3}{*}{ Alleles } & \multicolumn{3}{|c|}{ Markers } \\
\hline & \multicolumn{3}{|c|}{ BM7225 } \\
\hline & $\mathrm{BI}(\mathrm{N}=156)$ & $\mathrm{C}(\mathrm{N}=81)$ & $\mathrm{AA}(\mathrm{N}=98)$ \\
\hline$* 96$ & 0.18 & 0.24 & 0.36 \\
\hline$* 98$ & - & 0.03 & - \\
\hline$* 100$ & 0.01 & 0.04 & - \\
\hline$* 102$ & 0.13 & 0.10 & 0.27 \\
\hline *104 & 0.16 & 0.11 & 0.15 \\
\hline$* 106$ & 0.10 & 0.16 & 0.07 \\
\hline$* 108$ & 0.08 & 0.13 & 0.10 \\
\hline$* 110$ & 0.13 & 0.05 & 0.01 \\
\hline$* 112$ & 0.16 & 0.05 & 0.02 \\
\hline$* 114$ & 0.05 & 0.09 & 0.02 \\
\hline \multirow[t]{2}{*}{$\mathrm{H}$} & 0.86 & 0.87 & 0.77 \\
\hline & \multicolumn{3}{|c|}{ BMS694 } \\
\hline$* 135$ & - & - & 0.01 \\
\hline$* 141$ & 0.21 & 0.02 & 0.26 \\
\hline$* 143$ & 0.02 & 0.20 & - \\
\hline$* 145$ & 0.43 & 0.65 & 0.62 \\
\hline$* 147$ & 0.10 & 0.06 & 0.06 \\
\hline$* 149$ & 0.08 & - & - \\
\hline$* 151$ & 0.13 & 0.07 & 0.05 \\
\hline$* 153$ & 0.03 & - & - \\
\hline \multirow[t]{2}{*}{$\mathrm{H}$} & 0.74 & 0.53 & 0.54 \\
\hline & \multicolumn{3}{|c|}{ BMS2145 } \\
\hline$* 148$ & 0.15 & - & 0.16 \\
\hline$* 150$ & 0.07 & 0.08 & 0.07 \\
\hline$* 152$ & 0.24 & 0.10 & 0.06 \\
\hline$* 154$ & 0.22 & 0.26 & 0.31 \\
\hline$* 156$ & 0.14 & 0.16 & 0.13 \\
\hline$* 158$ & 0.05 & 0.08 & 0.03 \\
\hline$* 160$ & 0.05 & 0.14 & 0.10 \\
\hline$* 162$ & 0.07 & 0.13 & 0.13 \\
\hline$* 164$ & 0.01 & 0.05 & 0.01 \\
\hline \multirow[t]{2}{*}{$\mathrm{H}$} & 0.84 & 0.85 & 0.83 \\
\hline & \multicolumn{3}{|c|}{$\mathrm{T} 495 \mathrm{M}$} \\
\hline$*^{*} T$ & 0.98 & 0.92 & 0.96 \\
\hline$* M$ & 0.02 & 0.08 & 0.04 \\
\hline $\mathrm{H}$ & 0.03 & 0.15 & 0.08 \\
\hline STR mean $\mathrm{H}$ & 0.81 & 0.75 & 0.71 \\
\hline Mean $\mathrm{H}$ & 0.62 & 0.60 & 0.57 \\
\hline
\end{tabular}

$\mathrm{N}$ = sample size; genotype frequencies may be obtained with the authors, on request.

breeds probably results from its crossbreeding composition. High levels of STR genetic diversity in the BI herd has already been described (Almeida et al., 2003, 2007; Duarte et al., 2005; Oliveira et al., 2005). The Charolais herd presented the highest variability concerning the T945M polymorphism.
The occurrence of some exclusive alleles is probably related to the founder effect associated with the origin of each population. Literature data about these STR markers are scarce and there is no information about Bos primigenius indicus samples. The presence of the BMS694*149 and BMS694*153 alleles only in the Brangus Ibagé population suggests that they possibly originated from B. p. indicus (Zebu), as these alleles have not been described for other B. p. taurus samples so far investigated.

The PCR-RFLP method that we used to analyze the T945M SNP was efficient to detect this mutation and allowed the detection of a low frequency of the $M$ allele in the three populations. These data agree with those of Liefers et al. (2004), who verified a frequency of 0.07 in a population of 323 Holstein-Friesian cows and did not detect TT animals.

In cattle, as in other mammalian species, there is a positive relationship between circulating leptin and fat content (Murdoch et al., 2005) and leptin also seems to play a role in reproduction (Kendall et al., 2004; Kadokawa et al., 2006). Leptin action is mediated by the leptin receptor protein and LEPR mRNA abundance is increased by acute food restriction (Murdoch et al., 2005). Therefore, the analyses of the leptin receptor gene polymorphisms could be useful to understand the reproductive performance and weight gain variation in cattle. It is possible that there is an effect of STR polymorphisms on animal performance because these markers could affect gene regulation. Even being distant from the gene they regulate, they could alter the primary, secondary or tertiary DNA structure by binding to transcription factors, or by affecting RNA splicing or edition (Li et al., 2004).

The absence of an association between the molecular markers analyzed and $\mathrm{CI}$, WFC (in $\mathrm{BI}$ ) or between ADG and pregnancy rates (in AA and $\mathrm{C}$ ) suggests that there is no effect of these polymorphisms on these cattle production measurements in the postpartum period. However, the parameters here investigated are indirect measurements of reproductive performance and fat depots.

Liefers et al. (2004) verified an association between the T945M mutation with circulating leptin concentrations during late pregnancy, but not during lactation. As the cows analyzed in this study were in lactation period, the negative results do not exclude possible effects of these polymorphisms on cows weight gain or reproduction during other life periods. In species such as mouse and human, mutations at LEPR seem to be associated with obesity (Clément and Ferré, 2003; Zhang et al., 1994).

In $\mathrm{AA}$ and $\mathrm{C}$ samples the objective was to verify the joint effect of molecular markers, nutrition, weight gain, and hormone treatment on the reproductive performance of postpartum cows. The pregnancy rates were dependent on weight gain and on hormone treatment (Terra et al., 2008), but the molecular markers analyzed did not seem to influence weight gain or reproduction. 
Table 3 - Descriptive statistics for CI and WFC in Brangus Ibagé, for ADG, P1 and P2 in Aberdeen Angus and Charolais populations, in relation to hormone treatment and nutrition groups.

\begin{tabular}{|c|c|c|c|c|c|c|c|}
\hline \multicolumn{8}{|c|}{ Breeds } \\
\hline \multicolumn{8}{|c|}{ Brangus Ibagé } \\
\hline & & Mean & se & Minimum & Maximum & & \\
\hline & $\mathrm{CI}^{\mathrm{a}}$ & 549.71 & 41.72 & 352.0 & 933.2 & & \\
\hline & $\mathrm{WFC}^{\mathrm{b}}$ & 351.56 & 4.35 & 235.1 & 510.4 & & \\
\hline \multicolumn{8}{|c|}{ Aberdeen Angus } \\
\hline \multirow[t]{2}{*}{ Groups $^{\mathrm{d}}$} & \multirow[t]{2}{*}{ Number } & \multicolumn{4}{|c|}{$\mathrm{ADG}^{\mathrm{c}}$} & \multicolumn{2}{|c|}{ Pregnancy (\%) } \\
\hline & & Mean & se & Minimum & Maximum & P1 & $\mathrm{P} 2$ \\
\hline A0 & 26 & 113.65 & 37.60 & -266.80 & 544.00 & 77 & 96 \\
\hline $\mathrm{A} 2$ & 20 & 63.44 & 41.86 & -190.90 & 425.90 & 85 & 95 \\
\hline A5 & 7 & 169.07 & 46.44 & -054.70 & 324.70 & 71 & 86 \\
\hline $\mathrm{B} 0$ & 15 & 102.65 & 49.44 & -151.30 & 560.00 & 73 & 100 \\
\hline B2 & 13 & 170.28 & 58.47 & -242.70 & 463.20 & 69 & 92 \\
\hline B5 & 17 & 57.11 & 58.55 & -296.80 & 575.30 & 59 & 82 \\
\hline Total & 98 & 103.38 & 20.03 & -296.80 & 575.30 & 73 & 94 \\
\hline \multicolumn{8}{|c|}{ Charolais } \\
\hline \multirow[t]{2}{*}{ Group $^{\mathrm{d}}$} & \multirow[t]{2}{*}{ Number } & \multicolumn{4}{|c|}{$\mathrm{ADG}^{\mathrm{c}}$} & \multicolumn{2}{|c|}{ Pregnancy (\%) } \\
\hline & & Mean & se & Minimum & Maximum & P1 & $\mathrm{P} 2$ \\
\hline A0 & 14 & 219.07 & 61.33 & -97.00 & 832.00 & 50 & 93 \\
\hline A2 & 11 & 224.45 & 97.66 & -244.00 & 637.00 & 64 & 91 \\
\hline A5 & 15 & 308.60 & 63.16 & -255.00 & 812.00 & 43 & 93 \\
\hline B0 & 19 & 261.47 & 36.99 & -85.00 & 486.00 & 79 & 100 \\
\hline B2 & 12 & 228.92 & 59.45 & -52.00 & 575.00 & 67 & 75 \\
\hline B5 & 12 & 115.51 & 51.35 & -219.00 & 442.00 & 67 & 67 \\
\hline Total & 83 & 232.12 & 24.77 & -278.00 & 832.00 & 60 & 88 \\
\hline
\end{tabular}

${ }^{\mathrm{a}} \mathrm{CI}=$ calving interval in days; ${ }^{\mathrm{b}} \mathrm{WFC}=$ weight at first calving in $\mathrm{kg} ;{ }^{\mathrm{c}} \mathrm{ADG}=$ average daily weight gain in grams; ${ }^{\mathrm{d}} \mathrm{A}$ groups: $960 \mathrm{DM}$ ha ${ }^{-1}$; $\mathrm{B}$ groups: $400 \mathrm{~kg} \mathrm{DM} \mathrm{ha}^{-1}$; A0 and B0 definitive weaning; A2, B2: 2 mg of estradiol benzoate treatment; A5, B5: $5 \mathrm{mg}$ of estradiol benzoate treatment; se: standard error: P1: pregnancy frequency at day 60; P2: pregnancy frequency at day 127.

Many genetic and environmental factors influence reproductive performance and weight gain, with each individual gene having a small effect. As a matter of fact, mutations in other genes, mainly in leptin, are being described as affecting cattle weight gain and reproduction (Almeida et al., 2003, 2007; Liefers et al., 2002, 2003, 2005).

\section{Conclusions}

The analysis of three STRs and one SNP at the LEPR gene indicated a high variability of the beef cattle populations herein investigated, suggesting that the artificial selection applied to the breeds has not reduced their diversity, at least in these systems. Two alleles (BMS694*149 and $B M S 694 * 153)$ were exclusive to Brangus Ibagé, suggesting a likely B. p. indicus (Zebu) origin. No association between these markers and CI or WFC in Brangus Ibagé, and ADG and pregnancy rates in Aberdeen Angus and Charolais animals was detected. These negative results suggest that the LEPR gene polymorphisms, at least those herein described, do not influence postpartum cows production. This paper describes a cheap and effective new method to analyze T945M polymorphisms in cattle populations.

\section{Acknowledgments}

We are grateful to Dr. João Francisco de Oliveira and Dr. Luis Ernani Henkes for helping with sample collections and for the preparation of the reproductive performance file. This work was supported by Programa de Apoio a Núcleos de Excelência (PRONEX), Fundação de Amparo a Pesquisa do Estado do Rio Grande do Sul (FAPERGS), Financiadora de Estudos e Projetos (FINEP), Conselho Nacional de Desenvolvimento Científico e Tecnológico (CNPq), Coordenadoria de Estudos e Projetos (CAPES), and EMBRAPA Pecuária Sul.

\section{References}

Almeida SEM, Almeida EA, Moraes JCF and Weimer TA (2003) Molecular markers in the LEP gene and reproductive performance of beef cattle. J Anim Breed Genet 120:106-113. 
Almeida SEM, Almeida EA, Terra G, Neves JPN, Gonçalves PB and Weimer TA (2007) Association between molecular markers linked to the leptin gene and weight gain in postpartum beef cows. Ciência Rural 37:206-211.

Banks WA and Farrell CL (2003) Impaired transport of leptin across the blood-brain barrier in obesity is acquired and reversible. Am J Physiol Endocrinol Metab 285:10-15.

Bartha T, Sayed-Ahmeda A and Rudas P (2005) Expression of leptin and its receptors in various tissues of ruminants. Domest Anim Endocrinol 29:193-202.

Chilliard Y, Delavaud C and Bonnet M (2005) Leptin expression in ruminants: Nutritional and physiological regulations in relation with energy metabolism. Domest Anim Endocrinol 29:3-22.

Clément K and Ferré P (2003) Genetics and the pathophysiology of obesity. Pediatr Res 53:721-724.

Duarte LBH, Moraes JCF and Weimer TA (2005) Diversity of microsatellites linked to the FSH $\beta$ gene, their usefulness for individual identification and association with reproductive performance. Ciência Rural 35:145-149.

Kadokawa H, Blache D and Martin GB (2006) Plasma leptin concentrations correlate with luteinizing hormone secretion in early postpartum Holstein cows. J Dairy Sci 89:3020-3027.

Kappes SM, Keele JW, Stone RT, McGraw RA, Sonstegard TS, Smith TP, Lopez-Corrales NL and Beattie CW (1997) A second-generation linkage map of the bovine genome Genome Res 7:235-249.

Kendall NR, Gutierrez CG, Scaramuzzi RJ, Baird DT, Webb R and Campbell BK (2004) Direct in vivo effects of leptin on ovarian steroidogenesis in sheep. Reproduction 128:757765.

Li Y-C, Korol AB, Fahima T and Nevo E (2004) Microsatellites within genes: Structure, function, and evolution. Mol Biol Evol 21:991-1007.

Liefers SC, Te Pas MFW, Veerkamp RF and Van Der Lende T (2002) Associations between leptin gene polymorphisms and production, live weight, energy balance, feed intake, and fertility in Holstein heifers. J Dairy Sci 85:1633-1638.

Liefers SC, Te Pas MFW, Veerkamp RF, Chilliard Y, Delavaud C, Gerritsen R and Van Der Lende T (2003) Association of leptin gene polymorphisms with serum leptin concentration in dairy cows. Mamm Genome 14:657-663.

Liefers SC, Veerkamp RF, Te Pas MFW, Chilliard Y and Van Der Lende T (2005) Genetics and physiology of leptin in periparturient dairy cows. Domest Anim Endocrinol 29:227238 .

Liefers SC, Veerkamp RW, Te Pas MFW, Delavaud C, Chilliard $Y$ and Van Der Lende T (2004) A missense mutation in the bovine leptin receptor gene is associated with leptin concentrations during late pregnancy. Anim Genet 35:138-141.

Lowman BG, Scott N and Somerville S (1973) Condition scoring beef cattle (Bulletin, 6). East of Scotland College of Agriculture, Edinburgh, 8 pp.
Miller SA, Dykes D and Polesky HF (1988) A simple salting out procedure for extracting DNA from human nucleated cells. Nucleic Acids Res 16:1215.

Murdoch GK, Dixon WT, Okine EK and Christopherson RJ (2005) Bovine tissue mRNA abundance related to acute cold exposure and acute feeding restriction. Can J Anim Sci 85:157-164

Nei M (1978) Estimation of average heterozygosity and genetic distance in a small number of individuals. Genetics 89:583590.

Nonaka S, Hashizume T and Kasuya E (2006) Effects of intracerebroventricular injections of leptin on the release of luteinizing hormone and growth hormone in castrated calves. Anim Sci J 77:196-200.

Oliveira JFC, Neves JP, Almeida EA, Steigleder CS, Moraes JCF, Gonçalves PBD and Weimer TA (2005) Association between reproductive traits and four microsatellites in Brangus-Ibagé cattle. Genet Mol Biol 28:54-59.

Oliveira JFC, Neves JP, Moraes JCF and Gonçalves PBD (2002) Caracterização de aspectos produtivos de vacas Brangus Ibagé com distintos graus de fertilidade. Ciência Rural 32:663-667 (Abstract in English).

Oliveira NM, Salomoni E and Leal JJB (1998) Genetic and environmental effects on growth of $3 / 8$ Nelore X 5/8 Aberdeen Angus beef cattle derived from different crossbreeding schemes. Arch Latinoam Prod Anim 6:173-188.

Park KS, Shin HD, Park BL, Cheong HS, Cho YM, Lee HK, Lee J-Y, Lee J-K, Oh B and Kimm K (2006). Polymorphisms in the leptin receptor (LEPR) - putative association with obesity and T2DM. J Hum Genet 51:85-91.

Pfister-Genskow M, Hayes H, Eggen A and Bishop MD (1997) The leptin receptor (LEPR) gene maps to bovine chromosome 3q33. Mamm Genome 8:227.

Sambrook E and Russel J (2001) Molecular Cloning: A Laboratory Manual. 3th ed. Cold Spring Harbor Lab Press, New York, $2344 \mathrm{pp}$.

Terra GH, Gonçalves PBD, Oliveira JFC, Weimer TA and Neves JP (2008) Indução da ovulação em vacas de corte com diferentes ofertas forrageiras durante o período pós-parto. CAB 9:219-225 (Abstract in English).

Wilm HG, Costello DF and Klipple GE (1944) Estimating forage yield by the double-sampling methods. Agron J 36:194-203.

Zhang Y, Proenca R, Maffei M, Barone M, Leopold L and Friedman JM (1994) Positional cloning of the mouse obese gene and its human homologue. Nature 372:425-432.

\section{Internet Resources}

Código de Ética Profissional do Médico Veterinário, http://www. redevet.com.br/noticias/etica.htm (March 1, 1999).

International Guiding Principles for Biomedical Research Involving Animals, 1985, http://www.cioms.ch/1985 texts of_guidelines.htm (March 1, 1999).

Associate Editor: Luiz Lehmann Coutinho

License information: This is an open-access article distributed under the terms of the Creative Commons Attribution License, which permits unrestricted use, distribution, and reproduction in any medium, provided the original work is properly cited. 